\title{
The feasibility of introducing solar ovens to rural women in Maphephethe
}

\author{
Merridy Wilson and J Maryann Green
}

\section{OPSOMMING}

Vorige navorsing het bewys dat die potensiaal vir die bemagtiging van baie landelike vroue in ' $n$ beter manier van beide kook en die versameling van brandhout lê. Die vele huishoudelike pligte van vroue kan so verlig word. 'n Sonkookprojek is na aanleiding van hierdie bevinding in Maphephethe, ' $\mathrm{n}$ landelike gemeenskap omtrent $80 \mathrm{~km}$ wes van Durban, geïnisieer.

Die doel met die projek was drievoudig: om die sonoondtegnologie in die gebied bekend te stel, om ' $n$ kookprofiel op te stel ten einde die geskiktheid van sonkookmetodes vir die plaaslike omstandighede te bepaal, en om die mense te leer hoe om eenvoudige, goedkoop sonoonde te bou.

Formele vraelyste, fokusgroepe en informele gesprekke is gebruik om die data in te samel en om die nuwe tegnologie aan die gemeenskap bekend te stel.

Die resultate dui daarop dat sonkook in Maphephethe moontlik is, alhoewel sekere aspekte aandag moet geniet en die tegnologie daarvolgens aangepas moet word. Die geslagstereotipes wat aan tegnologieoordrag verbonde is, is bespreek, en ' $n$ pad vorentoe is aangewys om die tegnologie meer aanvaarbaar te maak.

\section{- Ms M Wilson}

- Dr JM Green

Community Resources

University of Natal, Pietermaritzburg

\section{INTRODUCTION}

Yes I collect wood. I use it for cooking and heating water. We collect wood twice a week and it is scarce now. It takes almost the whole day to collect which is about 7 to 8 hours a day (Woman from Maphephethe, cited in Annecke, 1998a).

The poverty of many rural communities means that access to household energy sources is limited. Households are often dependent on finite and unpredictable sources of income, and energy needs (as all other household needs) must be met within these financial constraints. As a result many families depend on free energy sources such as firewood. It has been reported that $75 \%$ of the fuel consumed in the rural areas of South Africa is firewood, an estimated 10 million tons per year (Palmer Development Group, 1997). Collecting firewood demands a large part of many rural women's daily household responsibilities (Hooper-Box, 1999). This work is extremely tiring as the women often have to walk long distances in search of wood which then has to be carried back to the homestead.

A survey conducted in Maphephethe, a rural community about $80 \mathrm{~km}$ to the west of Durban in KwaZuluNatal, found that collecting firewood was one of the greatest burdens for many women and that it had a significant impact on their quality of life (Green \& Erskine, 1998; 1999). The tiredness of these women can be 'felt' when one reads the report from which the above quote comes (Annecke, 1998a). The current solar cooking project was initiated in an effort to empower the women of Maphephethe by reducing their wood collection burden and thus improving their quality of life.

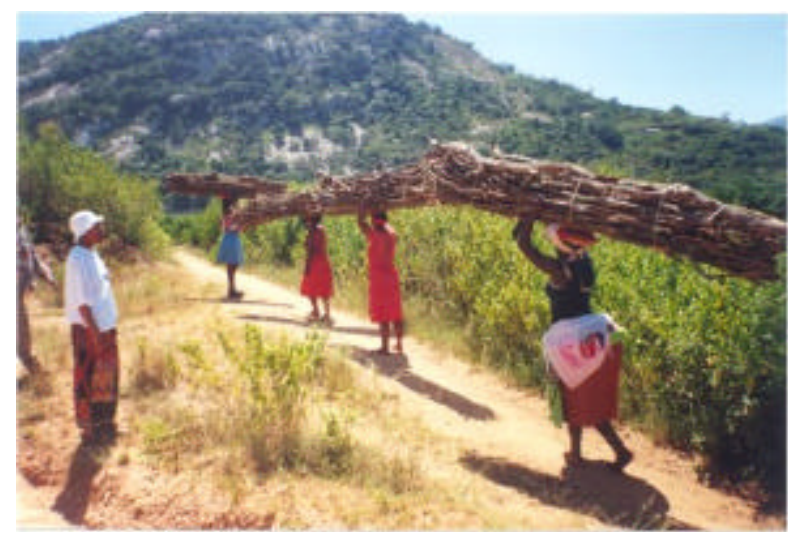

FIGURE 1: THE TIRESOME COLLECTION OF HALF A WEEK'S FIREWOOD 


\section{Background of solar cooking}

Solar cooking is not a new idea. The first solar cooker was designed between 1740 and 1799 (Palmer Development Group, 1997; Solar Cooking FAQ, 1999). Moreover, solar cooking increased worldwide in recent years. Solar cooking competitions and exhibitions take place each year in the USA. India has a National Solar Cooker Programme that distributed approximately 70000 cookers at subsidised prices. In Pakistan 1780 cookers were sold at subsidised prices between June 1985 and June 1987, and 100000 solar cookers are used in China (Karekezi \& Ranja, 1997).

Southern African development in this area has been somewhat slow. Although individuals have been experimenting with solar cookers for some time, the first commercial activity began in 1993 when the Sunstove company was launched (Palmer Development Group, 1997). Since then studies have been conducted to test the feasibility of different types of solar stoves (Palmer Development Group, 1997; Konttinen, 1995; Grundy \& Grundy, 1999; Rodgers, 1994).

Several types of solar cookers are available. There are three main designs, namely box cookers, panel cookers and parabolic cookers. (See the Solar Cooking Archive at http://www.solarcooking.org for more information on the different types of solar cookers, how they work, and how to build them.)

Solar cooking depends on direct rays of the sun. Reflective sloped sides, angled panels or a hemisphere is used on a (preferably) black cooking pot placed in the centre. The base plate (if present) is black, absorbing the sun's heat, and a Perspex lid traps the heat as in the greenhouse effect. The food cooks by means of a combination of radiant sunrays, conduction from the base plate and convection within a closed space. The oven should be rotated to face the sun at all times for the best effect.

The different cookers have been tested for suitability in rural and urban areas throughout the country. Various solar cooker models were comprehensively tested by 66 families and 14 institutions in three areas in the North West region of South Africa. In general, the study found positive views towards solar cooking with the solar cookers being used on $38 \%$ of all days within the one year test period, and $93 \%$ of the sample were satisfied with their solar cooking attempts. Solar cookers and wood fires were found to be the most frequently used cooking methods during the study period, followed by gas, paraffin and electricity. A 38\% overall fuel savings was found. Time and money savings were cited as the main impacts on women. Other possible macro-economic impacts included: cumulative savings; decreased air pollution from wood use (health benefits); time savings; and employment opportunities (Palmer Development Group, 1997).

\section{Empowerment through improved cooking methods}

Wilson \& Ramphele (1989) noted that the concept of development must include processes that facilitate the widening of opportunities for individuals and communities. The solar oven has the potential to contribute to such an outcome. The link between improved household energy sources and enterprise possibilities has great potential for the empowerment of rural women, as many projects in a wide range of countries have shown. Stove projects in Kenya indicated that improved stoves had a direct effect on the emancipation and general development of women. Housewives with better cooking facilities were more likely to become involved in development projects and were more pro-active in enhancing their living conditions (Kammen, 1993; Karekezi \& Ranja, 1997). Two specific examples of solar cooking projects will be presented here to provide an indication of the types of projects being carried out and the benefits of these for the local women.

The Ecuadorian Institute of Research and Training of Women (IECAIM) initiated a project in Quito in 1994 involving the construction and commercialisation of solar cookers. Three hundred and fifty women have benefited by this project and 4 micro-organisations were set up through women's organisations. The women were trained in the micro enterprise development and other aspects of commercialisation. The material for the construction of 90 solar cookers was given to each of the 4 groups. They now sell solar cookers, teach the use and importance of the cookers to people in their community and the income that they receive from this allows them to improve their standard of living (Solar cookers in Equador, 1998).

Solar baking has also been most successful in a poor neighbourhood of Ciudad Obergon in Mexico. In this project, women were trained in the construction of solar ovens which have been used in micro-bakery enterprises. During the course of a two year planning programme whilst funding was sought, the women themselves worked out their business plan, including who would be involved, what they would bake and how they would advertise. The design of the project also included a comprehensive follow up programme. The bakery now sells all that it produces each day and the gross profit is twice what is spent on ingredients. Ten percent of the money is reserved for the loan repayment and the other is divided up for salaries (Stone, 1998).

\section{OBJECTIVES OF THE MAPHEPHETHE SOLAR COOKING PROJECT}

In light of the previous research conducted in Maphephethe, together with the positive outcomes of other solar cooking projects world wide, this project was initiated to achieve the following objectives:

1 The introduction of solar oven technology to the area

2 To conduct a cooking profile to assess the suitability of the solar ovens for the local conditions, family structures and cooking habits 
3 To teach people to build simple, cheap solar ovens made from a cardboard box, in order to introduce this new concept of cooking.

\section{METHODOLOGY}

Rodgers (1994) outlined the "Method of Multiple Introduction" to be used for innovations that might require a change in behavioural habits. The process is a four stage one: initial introduction, structured follow up, adaptation of the innovation to local conditions and the reintroduction of the adapted innovation. The aim of this method of multiple introduction is to accommodate the local conditions that influence the acceptability of the innovation and to allow people enough time to carefully consider the value of the innovation and to see how it works. This solar oven project has operated at the first stage of the model, in order to introduce, for the first time, the idea of solar cooking as well as to assess the feasibility of the innovation for local conditions.

From the solar cooking literature, it is clear that certain factors are essential for the successful introduction of solar cooking. Not only are the technical constraints important, but the social and cultural norms of the people must be considered. Many solar cooking projects have failed because the particular needs of the women were not taken into consideration, for example the need to cook at night rather than at midday when the sun is high (Hooper-Box, 1999; Annecke, 1998b; Karekezi \& Ranja, 1997). For this reason it was considered essential to conduct a cooking profile of the area, focussing on both the technical factors influencing the cooking system as well as the cooking habits of the community to establish whether the introduction of solar cooking would in fact meet the needs of the local people.

The information required for the cooking profile included:

- Weather conditions

- Price of fuel and ovens

- Household size

- Availability of appropriate sunny space

- Cooking techniques

- Cooking schedule (see Palmer Development Group, 1997).

A commercially manufactured Sunstove and a homemade oven constructed out of a cardboard box and lined with aluminium foil were used for cooking demonstrations. Formal questionnaires (administered by local women after a brief training session), focus group discussions and informal discussions were used to gather the appropriate information and to introduce the new technology to the community. These were conducted at weekly or fortnightly intervals over a period of three months (March to May, 1999). The notion of solar power is not foreign to Maphephethe as a project focussing on the installation of Solar Home Systems (SHS) for household electrification has been in progress for the past three years (Cawood, 1997).

At the start of each of the focus group sessions a pot of rice and a tin of tomato and onion relish was placed in the ovens to cook while the discussions took place. A brief talk was given explaining how the technology worked and how it should be used. The community members were encouraged to ask questions and to informally discuss the ovens, what they liked about them and any problems that they foresaw with their use. At the end of the group discussions which lasted about an hour each, the pots would be opened and all could have a taste of the food that had been cooked. Many bystanders stopped off to have a look at what was happening throughout the demonstrations, thus this method enabled us to introduce the technology to many more people than only those who attended the focus groups. Altogether approximately 200 people in the community saw the solar cookers in use during eight demonstrations.

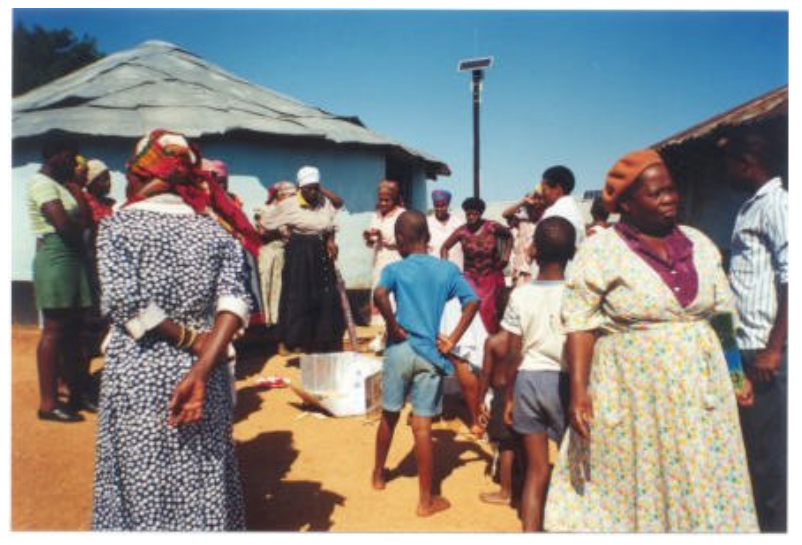
$\begin{array}{ll}\text { FIGURE 2: } & \text { THE SOLAR OVEN SITE SHOWING } \\ \text { THE HOME MADE SOLAR OVEN }\end{array}$

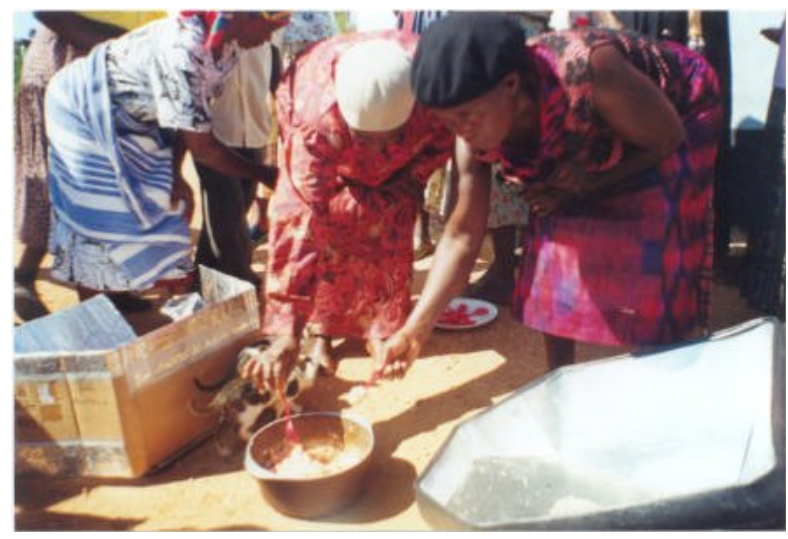

FIGURE 3: TESTING THE RESULTS FROM BOTH THE HOME MADE (ON THE LEFT) AND COMMERCIAL SOLAR (ON THE RIGHT) OVENS 
TABLE1: THE COOKING PROFILE FOR MAPHEPHETHE $(\mathrm{N}=\mathbf{2 0 4})$

\begin{tabular}{|c|c|c|}
\hline Profile Category & Sub-categories & Result \\
\hline \multirow[t]{3}{*}{ Mean weather conditions } & Annual Temperature & $21^{\circ} \mathrm{C}$ \\
\hline & Sunshine hours per day & 6.5 hours (Range $5.3-7.5$ ) \\
\hline & Full rainy days per annum & 28 days \\
\hline \multirow[t]{3}{*}{ Main cooking fuel } & Wood & $80 \%$ of households \\
\hline & Paraffin & $36 \%$ of households \\
\hline & Gas & $9 \%$ of households \\
\hline \multirow[t]{3}{*}{ Monthly Fuel Expenditures } & Wood & $\mathrm{R} 2.19$ \\
\hline & Paraffin & R34.24 \\
\hline & Gas (cooking and refrigeration) & $\mathrm{R} 117.43$ \\
\hline \multirow[t]{2}{*}{ Est. cost of solar ovens } & Commercial quality & R200 \\
\hline & Home made & R8 \\
\hline Household size: polygamous & Per wife & 9-10 people (max 24$)$ \\
\hline Appropriate place & Inside cooking & $88 \%$ of households \\
\hline \multicolumn{3}{|l|}{ Cooking techniques } \\
\hline \multirow[t]{2}{*}{ Gender issues } & Mothers cooking & $68 \%$ of households \\
\hline & Daughters cooking & $21 \%$ of households \\
\hline \multirow[t]{4}{*}{ Staple food types eaten } & Rice & $81 \%$ of households \\
\hline & Beans & $72 \%$ of households \\
\hline & Maize & $69 \%$ of households \\
\hline & Samp & $68 \%$ of households \\
\hline \multirow[t]{3}{*}{ Problem foods for cooking } & Bread & $20 \%$ of households \\
\hline & Rice & $15 \%$ of households \\
\hline & Meat & $9 \%$ of households \\
\hline Pots used for cooking & Black (but 3-legged) & $81 \%$ of households \\
\hline \multirow[t]{4}{*}{ Cooking schedule } & Midday & $55 \%$ of households \\
\hline & Evening & $47 \%$ of households \\
\hline & Both & $45 \%$ of households \\
\hline & Anytime & $9 \%$ of households \\
\hline
\end{tabular}

At the local high school, a workshop was held with 14 grade 11 Home Economics pupils during which they were taught to build the cardboard version of the oven. All materials were provided and the pupils were then asked to take the ovens home to try them out as part of a school project. The idea was for the pupils to keep a record of the types of food that they cooked and how well they found the ovens to work. These reports would form part of the cooking profile as a more experiential addition to the questionnaire data. It was hoped that the use of the solar ovens at home would enable a greater number of people in the community to be exposed to the new technology.
Nineteen women at two venues were also taught how to build the ovens, and materials and instructions were provided for further oven construction.

\section{RESULTS}

\section{The Cooking Profile}

Weather conditions The geographical area of Maphephethe has an average of 6.5 sunshine hours per day, the lowest being 5.3 and the highest being 7.5 at different times in the year. See Table 1. The 
mean annual temperature is 21 degrees Celsius. Only 28 days per year have more than $10 \mathrm{~mm}$ of rain (South African Weather Bureau, 1999). These weather conditions are suitable for solar cooking, the most important factor being the number of sunshine hours per day.

Price of fuel and ovens The availability of fuel often limits the choice of cooking system. In rural areas cooking fuels such as paraffin and electricity are often not readily available, or must be transported at considerable cost (Karekezi \& Ranja, 1997). Wood has been identified as the most commonly used fuel for cooking at Maphephethe, with $80 \%$ of the households interviewed using wood, 36\% paraffin, and 9\% gas (Green \& Erskine, 1999). Monthly expenditures on cooking fuel were found to be R2.19 for wood, R37.24 for paraffin and gas R117.43 (the latter including gas for refrigeration). (See Table 1.) Some households in the Eastern region of the area have been recently connected to the national grid, but having grid electricity did not seem to have much impact on the fuel used for cooking as many people cannot afford to purchase electric stoves. One of the main benefits of solar cooking is that the sun's energy is freely available with no cost involved.

The costs of the solar ovens would be an initial outlay cost only. The commercially manufactured Sunstoves cost R130 each for an order of 1 to 9 stoves, R120 for 10 to 49 , or R110 each for 50 or more (Bennett, 1999). With transportation costs from Johannesburg to Durban and profit to be made by a communitybased distributer, the estimated cost is approximately R200. None of the shop owners spoken to, were prepared to stock the ovens because they were concerned about the delivery of the ovens from Johannesburg. It would be essential to ensure that an appropriate transportation infrastructure is set up, if the commercial ovens are to be sold locally. Another concern raised by the shop owners was whether the people in the community could afford to pay R200 for the ovens. This price was not considered overly expensive by the women spoken to. However some form of monthly repayment system would be needed because R200 is too much for many of the families to outlay at one time. (The average monthly household income in Maphephetje is R1035. One quarter of the sample earn R500 and less per month - the household income in these cases is often one pension only.) The home-made cardboard box stove costs approximately R8 to produce and is thus affordable for many more people. The quality and durability of this stove is not as good as the more expensive stove, but it does provide a possible alternative for those who are unable to afford the Sunstove, and serves as a means of introducing the new technology.

Household size The average household size at Maphephethe is between 9 and 10 people (Green \& Erskine, 1998). Some households, however, have as many as 24 people. This may be a problem with the solar oven as the ovens are too small for large pots to be used. During the discussions some women said that they had to cook three times per day in very large, three-legged black pots in order to feed their families. In such situations, the solar oven may not be suitable. The use of the solar oven may then be only in terms of the heating of water for washing dishes and clothes. This in itself would represent a fuel savings in terms of wood use.

Availability of an appropriate sunny space The household needs to have a safe area outside where the cooking can be done. Concern was expressed by some of the women that the goats may try to tip the oven over in order to eat the food (Rodgers, 1994). This would mean than someone would have to watch the oven continually, thus negating the possible benefit of time savings. It was found that $88 \%$ of the people interviewed cooked inside at present. This finding would need to be explored further in order to assess whether cooking outside would be problematic for the majority of the people. The method of multiple introduction will be useful in order to overcome this problem in the long run. A structured follow up should be conducted to find out whether the foreseen problem of cooking outside has arisen and from here, the stage of adaptation could be implemented in order to find a way of overcoming the difficulties experienced (Rodgers, 1994).

Cooking Techniques Various issues were considered for this section of the cooking profile, including the types of foods most commonly eaten, the foods that people wish to cook differently, the types of pots used for cooking and who in the household is responsible for most of the cooking. Most of the household cooking is done by women, the mother cooking $68 \%$ of the time and the girls $21 \%$. (See Table 1.) Our goal of empowering the women in the community is thus in focus, as an improved means of cooking stands to benefit the women as the principal cooks and wood collectors.

The staple foods that were identified as being eaten by most households were as follows: rice $81 \%$, beans $72 \%$, maize $69 \%$, and samp $68 \%$. (See Table 1.) All of these foods are easily cooked in the solar oven. Samp and beans take a long time to cook and as such require vast amounts of energy resources. With the solar oven, these types of food could be placed in the sun to cook early in the day and by lunch or dinner should be cooked or almost cooked, possibly needing to be put over the fire for a short time only. From the informal discussions held with the women in the area, it seemed that the cooking of samp and beans in this way was seen as a major benefit of the solar oven.

The respondents were also asked which foods were a problem to cook using current methods. The most commonly noted food was bread $20 \%$, followed by rice $15 \%$ and meat $9 \%$. The solar oven is suitable for baking, a form of cooking required by $35 \%$ of the sample interviewed, and would provide an option for the cooking of bread. Rice cooks well in the solar ovens, as many people were able to see at the cook- 
ing demonstrations. Meat is more difficult to cook as it spoils if the temperature is not high enough. It was suggested that all meat and bean dishes should be finally cooked over the flames for 20 minutes before serving to ensure that any food spoilage is prevented.

Dark coloured pots are required for the solar oven to work efficiently as the dark pots absorb more heat than light coloured pots which reflect the heat away. It is important for dark coloured pots to be readily available since if such pots must first be purchased, the cost of using the oven rises. Eighty one per cent of the people interviewed stated that they made use of black pots for cooking. At first glance this appears to imply that the pots best suited for solar cooking are available. However from the informal discussions, it appeared that many of these black pots are actually large three legged cast iron pots which would not fit into the solar ovens. The availability of pots thus needs to be addressed.

Cooking Schedule The respondents were asked when they did most of their cooking (more than one time category could be chosen as many people cook more than once a day). Fifty five per cent stated that they cook at midday, the best time for the use of the solar cookers, $47 \%$ in the evening, $45 \%$ in the morning and $9 \%$ at anytime. Since it is impossible to use the solar oven in the evening, there are likely to be some people for whom the oven would require a vast change in cooking schedule. The solar ovens work well in the morning, midday and early afternoon and from the figures quoted above it seems that a significant proportion of the sample does cook within these times. It may be best to target the follow up study at these people first, allowing those for whom the adoption of the oven would require greater behavioural change, sufficient time to make the desired changes.

\section{General findings}

From the demonstrations held, it was found that the solar ovens were well received in the community. Much interest was shown, both by the participants in the focus groups and bystanders. The value of the demonstrations lies in the fact that the people are able to see and to touch the ovens, to feel how hot the pots become and to taste the food that has been cooked. It is believed that this experiential learning is likely to be more beneficial than simply being told about the ovens and how they work.

The Home Economics pupils who were taught to construct the ovens tested them out, with favourable results. Rice, samp and chicken curry were successfully cooked. Furthermore, the aim of introducing the new technology to greater numbers of people in the community, through the school children was realised. All of the children spoken to reported reactions of fascination and disbelief from family and friends when shown the solar oven. Two of the pupils taught their friends how to construct the ovens.
An assessment of the types of foods potentially marketable in the community was used as a starting point for the future income generation component of the project. Respondents were asked about the types of food that they thought could potentially be sold in Maphephethe (more than one food type could be noted). Sixty seven per cent of the respondents felt that biscuits could be sold, $61 \%$ cooked eggs, $57 \%$ bread, and $12 \%$ rice. All of these foods can be cooked in the solar oven. In the long term (post introduction stages), it is hoped that the solar ovens could be used for income generation purposes, with women in the community selling food they have cooked, producing and selling the ovens, and teaching others how to use the ovens.

\section{DISCUSSION}

From the results presented above, and the overall positive response to the new technology, it appears that although some problems are likely to be encountered, in general, the solar oven is suitable for the community at Maphephethe. The sunny weather conditions support the use of solar energy. Since the most commonly eaten foods can be cooked in the ovens, and a significant number of people cook during the day, further promotion efforts should have a good chance of success. The women are responsible for cooking and wood collection, thus the introduction of solar ovens to the area should be of direct benefit to them.

For successful dissemination of the technology it is essential that certain constraints are addressed. Changes in cooking habits would be required. Although the majority of the sample did cook at midday, a sizable proportion (46\%) cooked in the evening. Further study is needed to assess whether this is a cooking preference (which could be changed) or is linked to some other factor, such as having to work during the day. For most people cooking inside is the norm, yet the solar oven must be placed outside. For successful use of the solar oven, the routine of only indoor cooking would have to be changed. It seems that few people in Maphephethe would be able to adopt the new technology without making some adjustment to their current cooking practices. Perhaps a starting point for these changes is to emphasise that the solar oven is an additional cooking tool, rather than a replacement cooking method.

One of the main hindrances to widespread adoption of the solar ovens is the lack of infrastructure for delivery from Johannesburg, and the consequent unwillingness of local shop owners to stock the ovens. One possible means of addressing this issue is to train local people to produce the commercial ovens. This would require business skills training as well as the specifics of oven construction. According to Bennett (1999), this approach has been tried but was unsuccessful, as the quality of the locally produced ovens was poor and the price of the ovens did not compensate adequately for number of hours spent producing

The feasibility of introducing solar ovens to rural women in Maphephethe 
the stoves. Since the price of R200 is not affordable as a once off payment for many people, the establishment of some sort of repayment method is essential. A project in another province, funded by the Department of Minerals and Energy (DME), consigned ten Sunstoves to locally based entrepreneurs. In this manner the start-up capital for a solar stove business was provided. Once the ovens had been sold and paid for, the entrepreneur was able to buy another set. When purchasing the ovens, the buyer paid an initial deposit, followed by monthly repayments as agreed with the entrepreneur. The system worked well, and there were few bad debts (Bennett, 1999). This approach would address both the difficulty of paying R200 once off, and the lack of transportation infrastructure seen as a problem by the shopkeepers.

What has been described as the "gender tug-ofwar" (Rodgers, 1994) needs to be carefully approached if the possible benefits noted above are to be realised. Technology and any technological developments have traditionally been seen as falling within the men's arena and cooking and wood collection in the women's. In a solar cooking project in Zimbabwe, conflicts developed as these, once separate, areas now came together with the introduction of the solar oven. Some of the men who had attended the solar cooker building workshops said that they would not allow their wives to use the ovens (Rodgers, 1994). In a similar vein, researchers based in Lesotho encountered resistance from the men in the community towards the introduction of solar cooking because they were concerned about what the women would do with their spare time. One man then suggested that the men "could get more work out of their wives, since the solar cookers would reduce the time the women spent cooking"! (cited by Grundy \& Grundy, 1999:2). While the introduction of solar cooking technology does have the potential to confront gender stereotypes with respect to technological developments, it is important to be aware of the conflicts that may arise and the possible negative impact on the women. In the work done in Maphephethe, at no time was there any evidence that such conflict is imminent. Both men and women attended the cooking demonstrations and there did not seem to be any "gender tug-ofwar" at play. The introduction of the innovation is still in the early stages, and as the potential of the solar ovens becomes more widely accepted, gender conflicts may arise.

The importance of the transfer of knowledge as opposed to simply providing people with the technology has been noted by various authors (Rodgers, 1994; Introducing solar ovens to rural Kenya, 1999; Grundy \& Grundy, 1999). One of the women in our discussion groups remarked that for her the biggest problem with the solar ovens was that "she did not know how they could cook the food with only the sun". More work needs to be done in terms of introducing the technology and more time spent discussing the workings of the solar ovens with the people. Education is thus essential for the ovens to become accepted, otherwise the solar oven is likely to remain a new and foreign technology. Based on research conducted in Namibia, it was concluded that the best results were achieved when the local teachers were taught how to build the ovens. Since they already have an understanding of how to teach people, solar cooker construction was taught more effectively (Konttinen, 1995). This method of teaching people in the hopes that they will teach others is not always successful, according to reports from other solar cooking projects (Bennett, 1999). However, the school pupils who had learnt how to construct ovens did begin to teach others, both about how the ovens work and the construction thereof. Another important consideration, highlighted by this and other studies, is the importance of having local people involved in the promotion of the ovens (Grundy \& Grundy, 1999). When accompanied by the local interviewers, the researchers received a much better and more open response from the people in the community. In this way, introduction of the technology was supported, and the technology became less 'foreign'.

\section{THE PROPOSED WAY FORWARD}

On the basis of the work done in Maphephethe so far, and the lessons learned from the other solar cooking projects discussed, a proposed way forward can be outlined. The extension of this project however depends on the availability of funding.

The first step would be to set up a local committee to take responsibility for continuing the promotion of the solar cookers in a manner that suits the local conditions. This would ensure that the ovens would be adapted to the local conditions and that the project becomes sustainable in the long run. Continuing cooking demonstrations with a wider variety of food stuffs would be needed in order to expose more people to the solar ovens and make the range of foods that can be successfully cooked known. It may be useful to have a set of ovens that people could loan for a short period of time to try out before buying their own. It is essential that the financial constraints faced by so many households in the community be addressed. This would be best done by working through the solar cooking committee. Revolving credit schemes, which allow buyers to pay for their stoves over a few months, are an option (Bennett, 1999). In the long term, a possible solar cooker business could be set up. This could provide employment for the women of Maphephethe in a variety of ways, including the production of the ovens, selling of food and provision of cooking lessons.

\section{CONCLUSION}

From this study it seems that, in general, the introduction of solar ovens to the community of Maphephethe is feasible, although some constraints would need to be addressed. Since the women bear the total responsibility for the arduous task of wood collection as well as the household cooking, the solar oven has the 
potential to ease their workload and so to contribute to an improved quality of life. Although the solar oven seems to bridge the gap between technological development, which traditionally falls in the men's domain, and women's household responsibilities, the potential for what has been called the "gender tug-of-war" to develop must be remembered. If carefully promoted, however, it is believed that the solar oven could provide a means of confronting the gender constraints and stereotypes linked to technology transfer.

\section{REFERENCES}

ANNECKE, W. 1998a. Assistance to NREL regarding noneconomic determinants of energy use in rural areas of South Africa. Unpublished research report. Energy and Development Research Centre. University of Cape Town. South Africa.

ANNECKE, W. 1998b. Pebble-beds or paraffin? Agenda 38:43-47.

BENNETT, M. 1999. Personal communication. Sunstove Organisation.

CAWOOD, W. 1997. Maphephethe Non-grid SHS electrification programme, phase 2 (Final Report). Project No. EO 9704.

GREEN, JM \& ERSKINE, S. 1998. An energy audit of Maphephethe: Assessing present energy usage patterns as a precursor to the introduction and expansion of alternative energy resources. Final report. Community Resources. University of Natal. Pietermaritzburg.

GREEN, JM \& ERSKINE, S. 1999. Solar (photovoltaic) systems, energy use and business activities in Maphephethe, ZwaZulu-Natal. Development Southern Africa 16(2):221-237.

GRUNDY, RR \& GRUNDY, WN. Diffusion of innovation: Solar oven use on Lesotho. Available on line. URL: http:// solarcooking.org/lesotho1.htm. Accessed 13 June 2000

HOOPER-BOX, C. 1999. Cooking, cleaning, energy and gender. Land and Rural Digest 1(6):18-19.

KAMMEN, D. 1993. Introducing Solar Ovens to Rural

Kenya Available on line. URL: http://solarcooking.org/ kammen93.htm. Accessed 13 June 2000

KAREKEZI, S \& RANJA, T. 1997. Renewable Energy Technologies in Africa. London. Zed Books.

KONTTINEN, P. 1995. Solar Cookers for use in Namibia. Unpublished Thesis. Helsinki University of Technology.

PALMER DEVELOPMENT GROUP. 1997. Solar Cooker Field Test in South Africa. End-user acceptance. Report prepared on behalf of the Department of Minerals and Energy (DME), Pretoria and Deutsche Gesellschaft fur Technische Zusammenarbeit GmbH (GTZ), Eschborn.

RODGERS, PM. 1994. Solar Box cookers in Zimbabwe. The introduction of radical innovation in cooking. Unpublished thesis. University of California, Davis.

Solar cookers in Ecuador: Jobs and improved energy usage. 1998. Energia News, 2 (1):10-11.

SOLAR COOKING FAQ. Available on line. URL: http:// solarcooking.org/solarcooking-faq.htm Accessed $13 \overline{\text { June }}$ 2000.

SOUTH AFRICAN WEATHER BUREAU. 1999. Personal communication.

STONE, L. 1998. Solar baking under the Sonoran sun. Energia News 2(1):12-13.

WILSON, F \& RAMPHELE, M. 1989. Uprooting Poverty: The South African Challenge. Cape Town. David Philip. 